\title{
STUDIES ON THE SYSTEM LIME-FERRIC OXIDE-SILICA
}

\author{
By Milton D. Burdick
}

\section{ABSTRACT}

The equilibrium diagram of a part of the ternary system lime-ferric oxidesilica is presented. A comparison with the diagram of the lime-alumina-silica system shows that the presence of ferric oxide results in extension of the stability fields of the calcium silicates and the lowering of the liquidus and eutectic temperatures in much of the area investigated. Evidence from thermal analyses is offered of a limited solid-solution series between dicaleium silicate and ferric oxide, substantiated by an X-ray investigation. The amount of reduction of ferric oxide at the liquidus temperature of representative ternary mixtures is recorded. The applications to iron-rich cements are discussed.

\section{CONTENTS}

I. Introduction Page

II. Experimental methods_.

III. Stability fields _._.

1. $\mathrm{SiO}_{2}$

2. $\mathrm{CaO} . \mathrm{SiC}_{2}$

3. $3 \mathrm{CaO} .2 \mathrm{SiO}_{2}$

4. $2 \mathrm{CaO} . \mathrm{SiO}_{2}$

5. $3 \mathrm{CaO}^{\mathrm{SiO}} \mathrm{S}_{2} \ldots$

6. $\mathrm{CaO}_{2}$

IV. Reduction of ferric oxide in ternary mixtures

V. Applications _.

VI. Summary

VII. References

\section{INTRODUCTION}

The system lime-ferric oxide-silica is one of the ternary systems involving the major oxide components of portland cement which has not been thoroughly investigated. Further study of this system seemed desirable, since it might be applicable to high-iron cements, and because it would supply preliminary information necessary for an investigation of the quaternary system, $\mathrm{CaO}-\mathrm{Al}_{2} \mathrm{O}_{3}-\mathrm{Fe}_{2} \mathrm{O}_{3}-\mathrm{SiO}_{2}$, in the region of aluminous cements. In this study the phase relations have been determined in that portion of the system including from 15 percent to 65 percent of $\mathrm{CaO}$ and up to 65 percent of $\mathrm{Fe}_{2} \mathrm{O}_{3}$.

Previous investigators of a part of the system covered in this report [1] ${ }^{1}$ noted the presence of a stability field for the compound tricalcium silicate, reported no ternary compounds, and observed the inability of ferric oxide to prevent the $\beta-\gamma$ inversion of dicalcium silicate, except when present in high concentration. These findings are confirmed by the present study.

Two of the binary systems making up the ternary system under consideration have been investigated. These are the systems

\footnotetext{
1 Numbers in brackets indicate the literature references at the end of this paper.
} 
$\mathrm{CaO}-\mathrm{SiO}_{2}[2,3,4,5]$ and $\mathrm{CaO}-\mathrm{Fe}_{2} \mathrm{O}_{3}[6]$. The binary system $\mathrm{Fe}_{2} \mathrm{O}_{3}$ $\mathrm{SiO}_{2}$ has not been thoroughly studied, but an equilibrium diagram has been suggested [7].

In the determination of the primary and secondary phases of all preparations containing more than 30 percent of ferric oxide, liquids were developed with a sufficient concentration of ferric oxide to cause the persistent development of quench growths of calcium ferrites.

\section{EXPERIMENTAL METHODS}

Calcium carbonate, purified silica gel, and ferric oxide were the materials from which the mixtures studied were prepared. The calcium carbonate was of reagent quality for alkali determinations. Analyses showed 55.94 percent of $\mathrm{CaO}, 0.04$ percent of $\mathrm{SiO}_{2}, 0.02$ percent of $\mathrm{R}_{2} \mathrm{O}_{3}, 0.02$ percent of $\mathrm{MgO}$, and 44.03 percent was ignition loss. The silica gel was a commercial granular product, which was purified by boiling with concentrated nitric acid and subsequently thoroughly washed and dried. Treatment with hydrofluoric and sulfuric acids left an insoluble residue of 0.08 percent, based on the weight of the ignited silica, composed of 5 parts of $\mathrm{Al}_{2} \mathrm{O}_{3}$ and 3 parts of $\mathrm{Fe}_{2} \mathrm{O}_{3}$. The ferric oxide, by analysis, contained 0.40 percent of $\mathrm{SiO}_{2}, 99.28$ percent of $\mathrm{Fe}_{2} \mathrm{O}_{3}$, and 0.24 percent was ignition loss.

The samples for study were prepared by weighing appropriate amounts of the materials, correcting for ignition loss and impurities, grinding and intimately mixing in an agate mortar, sintering twice in a platinum crucible with intermediate grinding, and finally regrinding. Analyses of three mixtures showed close agreement between calculated and analyzed compositions.

A vertical-tube platinum-wound resistance furnace and control [8] was used for the high-temperature treatments.

Temperatures were measured by means of platinum-platinumrhodium thermocouples and a type $K$ potentiometer and a suspension galvanometer. The single thermocouples were compared with a calibrated couple. The differential thermocouple used in the determination of heating curves was calibrated frequently at the melting point of potassium sulfate, $1,067^{\circ} \mathrm{C},[18]$ and by determining the $\alpha-\beta$ inversion temperature of pure dicalcium silicate, $1,420^{\circ} \mathrm{C}[3]$.

Microscopic examination of the quenched samples was made with a petrographic microscope, and indices of refraction were measured by the immersion method.

\section{STABILITY FIELDS}

In figure 1 are shown the boundary lines of the primary phase areas. The stability fields of $\mathrm{SiO}_{2}, \alpha-\mathrm{CaO} \cdot \mathrm{SiO}_{2}, 2 \mathrm{CaO} \cdot \mathrm{SiO}_{2}$, and $\mathrm{CaO}$ are relatively large when compared with those of $3 \mathrm{CaO} \cdot 2 \mathrm{SiO}_{2}$, $3 \mathrm{CaO} \cdot \mathrm{SiO}_{2}$, and $2 \mathrm{CaO} \cdot \mathrm{Fe}_{2} \mathrm{O}_{3}$. The dots represent the mixtures investigated.

Isotherms have been inserted in figure 2 to show the temperatures of complete melting.

\section{1. $\mathrm{SiO}_{2}$}

The data on preparations in which tridymite occurs as the primary phase in equilibrium with liquid are given in table 1. 


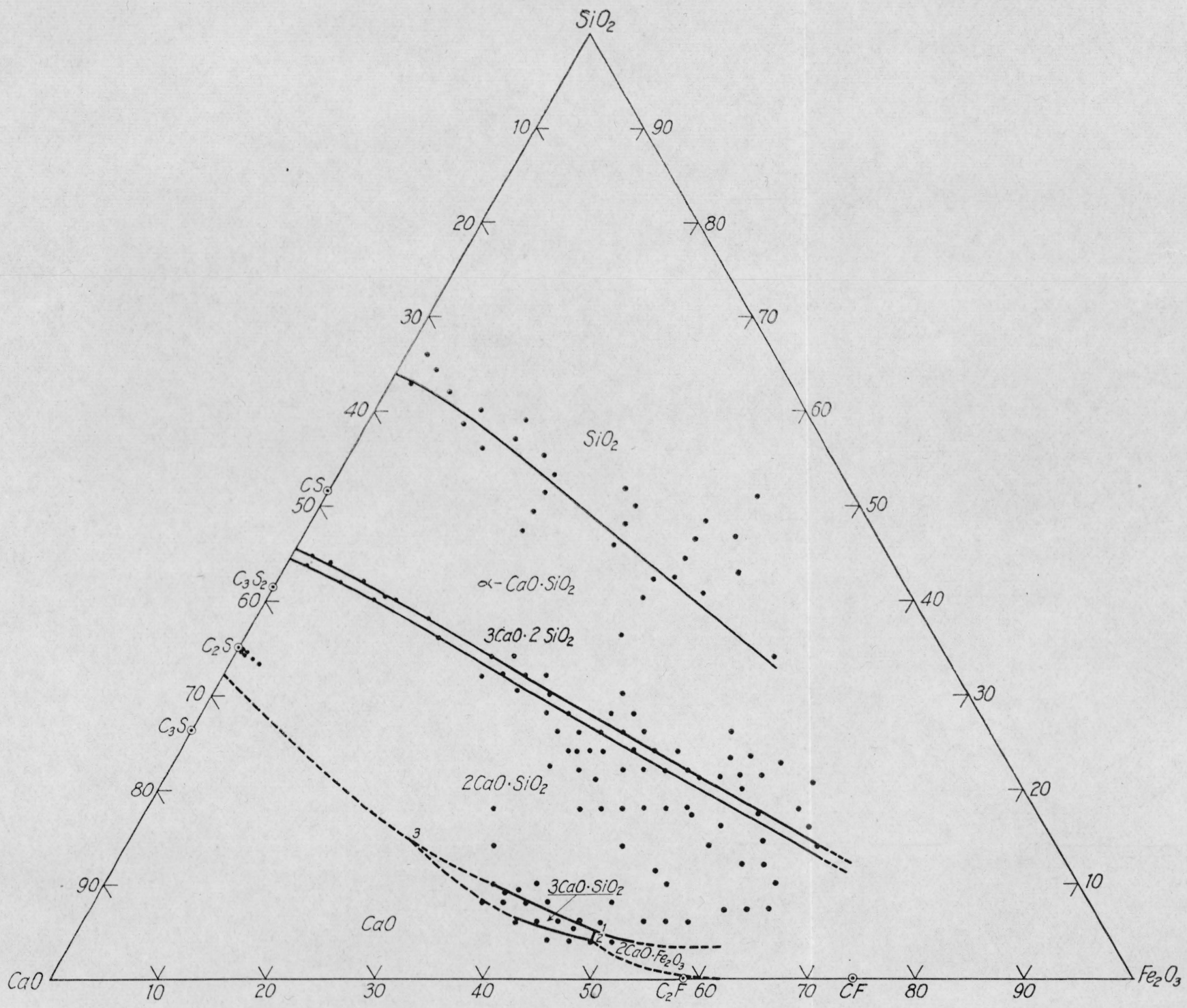

Figure 1.-Triangular concentration diagram of a part of the system $\mathrm{CaO}-\mathrm{Fe}_{2} \mathrm{O}_{3}-\mathrm{SiO}_{2}$, showing the limits of the stability fields. Dots represent the composition investigated. 


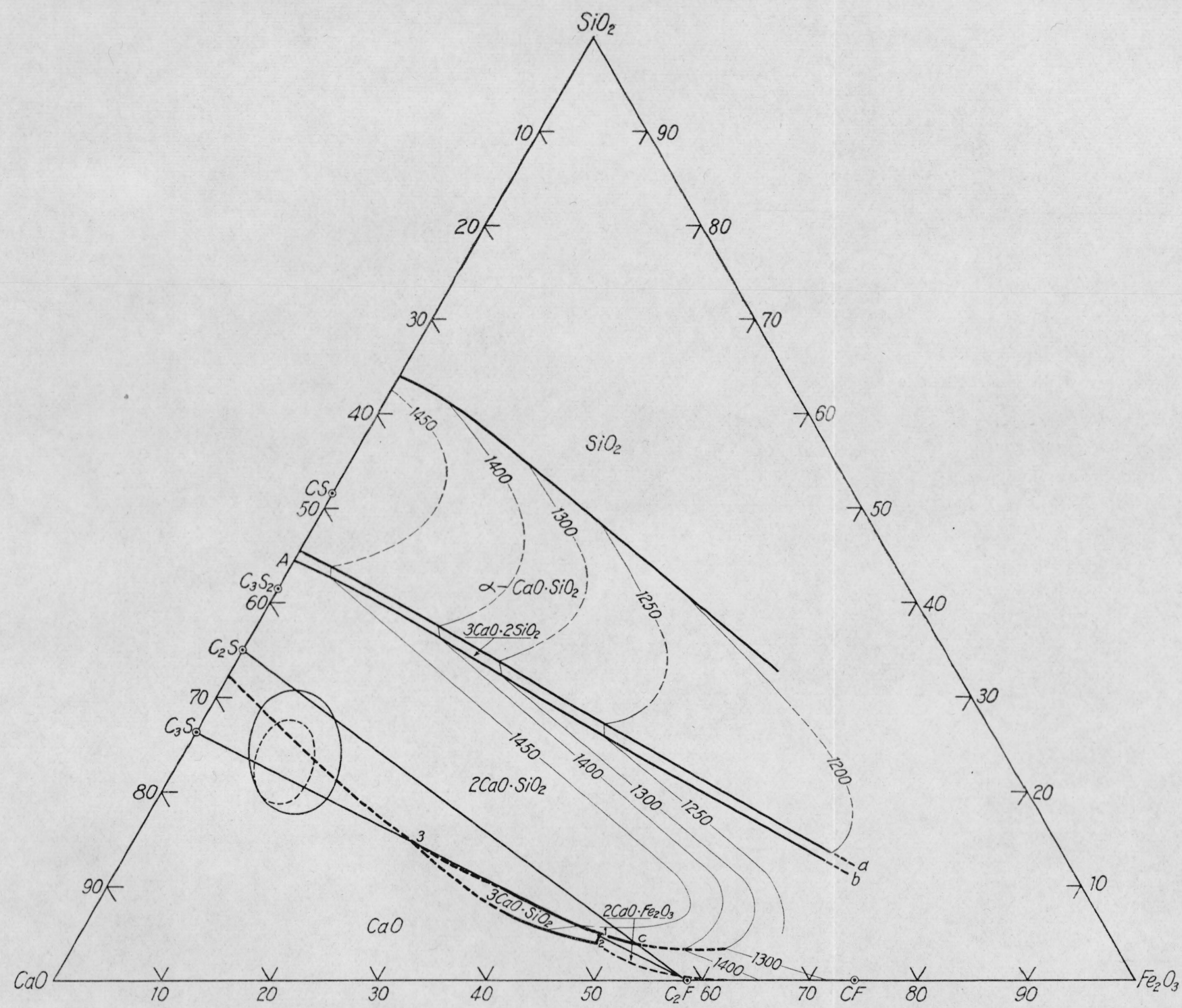

FIGURE 2.-Triangular concentration diagram of a part of the system $\mathrm{CaO}-\mathrm{Fe}_{2} \mathrm{O}_{3}-\mathrm{SiO}_{2}$ with isotherms showing temperatures of complete melting and composition triangles. 
Preparations treated for periods of an hour or less at appropriate temperatures contained crystalline silica identified as tridymite by its index of refraction and its birefringence. The characteristic lathlike shapes [9] were observed only in those preparations treated for longer periods of time before quenching.

TABLE 1.-Composition of and data on preparations determining the silica field

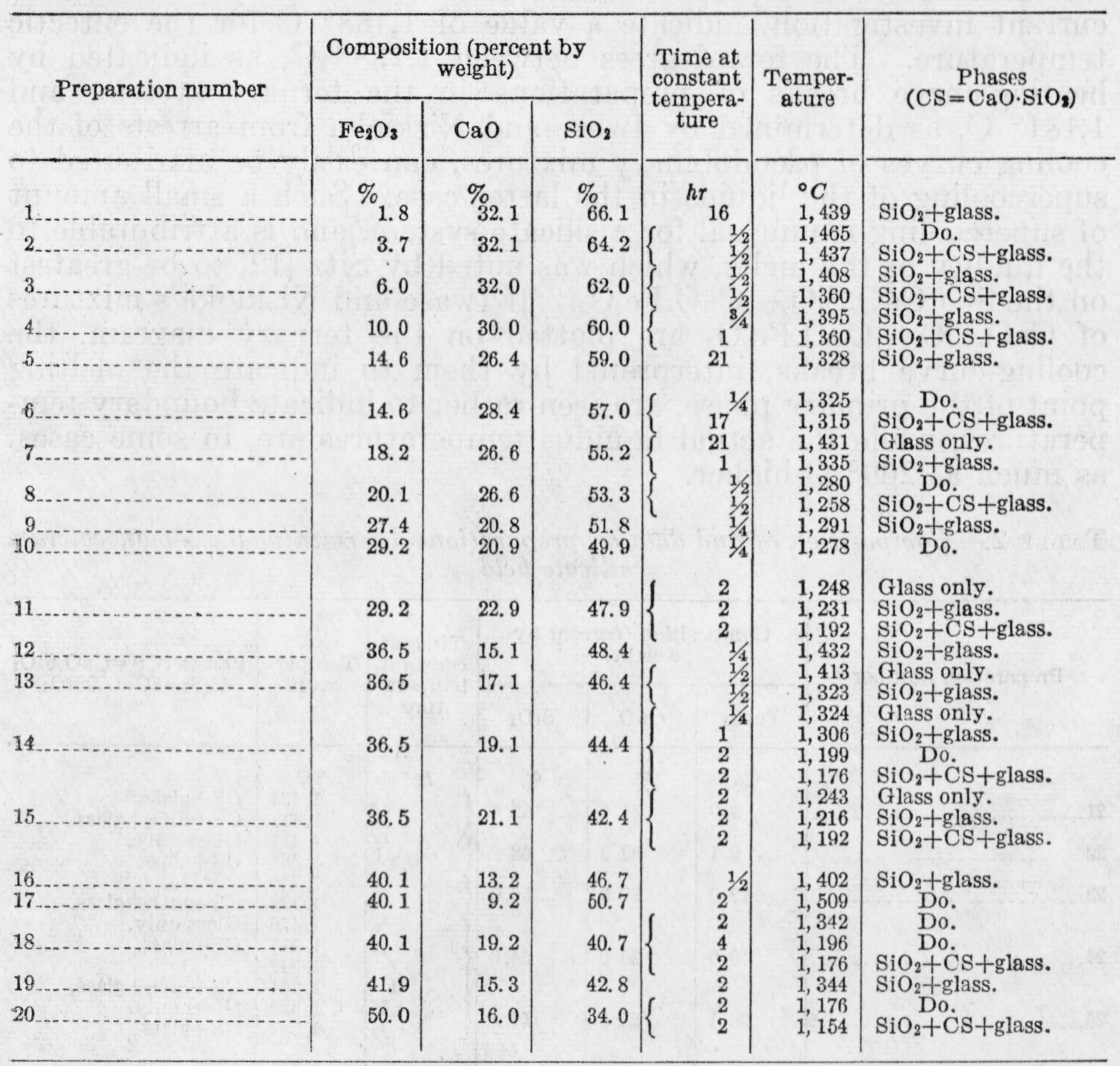

\section{2. $\mathrm{CaO} . \mathrm{SiO}_{2}$}

The data on preparations which determine the area within which pseudowollastonite $\left(\alpha-\mathrm{CaO} . \mathrm{SiO}_{2}\right)$ occurs as the primary phase are listed in table 2. Wollastonite $\left(\beta-\mathrm{CaO} . \mathrm{SiO}_{2}\right)$ was not observed in any of the quenched samples, since few were held below $1,200^{\circ} \mathrm{C}$ and none below $1,150^{\circ} \mathrm{C}$, which has been suggested as the true $\alpha-\beta$ inversion temperature of monocalcium silicate [10].

Iwase and Niskioka [11], in discussing the system $\mathrm{CaO}^{-\mathrm{SiO}_{2}-}$ $2 \mathrm{CaO} \cdot \mathrm{Fe}_{2} \mathrm{O}_{3}$, have described this as a simple binary system. Their diagram shows $\mathrm{CaO}$. $\mathrm{SiO}_{2}$ and $2 \mathrm{CaO} \cdot \mathrm{Fe}_{2} \mathrm{O}_{3}$ to be the only solid phases appearing on the liquidus curve with the eutectic at 45 percent $\mathrm{CaO} . \mathrm{SiO}_{2}$. Inasmuch as the compound $2 \mathrm{CaO} \cdot \mathrm{Fe}_{2} \mathrm{O}_{3}$ melts incongruently, mixtures of this with any other compound or oxide should be defined as a pseudobinary system. Also, as can be seen from figure 2, a join between the compounds $\mathrm{CaO} \cdot \mathrm{SiO}_{2}$ and $2 \mathrm{CaO} \cdot \mathrm{Fe}_{2} \mathrm{O}_{3}$ would 
cross the stability fields of $\mathrm{CaO} . \mathrm{SiO}_{2}, 3 \mathrm{CaO} .2 \mathrm{SiO}_{2}, 2 \mathrm{CaO} . \mathrm{SiO}_{2}$, $2 \mathrm{CaO} \mathrm{Fe}_{2} \mathrm{O}_{3}$, and $\mathrm{CaO}$. The eutectic temperature, reported by the above investigators, for mixtures of $\mathrm{CaO} . \mathrm{SiO}_{2}$ and $2 \mathrm{CaO} . \mathrm{Fe}_{2} \mathrm{O}_{3}$ containing from 50 to 90 percent of $\mathrm{CaO} . \mathrm{SiO}_{2}$ has a mean value of $1,181^{\circ}$ C. In the ternary system $\mathrm{CaO}-\mathrm{Fe}_{2} \mathrm{O}_{3}-\mathrm{SiO}_{2}$ the above mixtures are located in the composition triangle $\mathrm{CaO} . \mathrm{SiO}_{2}, 3 \mathrm{CaO} .2 \mathrm{SiO}_{2}, \mathrm{CaO} . \mathrm{Fe}_{2} \mathrm{O}_{3}$. Thermal analyses of preparations in this triangle, made during the current investigation, indicate a value of $1,188^{\circ} \mathrm{C}$ for the eutectic temperature. The few degrees between $1,188^{\circ} \mathrm{C}$, as indicated by heating-curve breaks of preparations in the ternary system, and $1,181^{\circ} \mathrm{C}$, as determined by Iwase and Niskioka from arrests of the cooling curves of pseudobinary mixtures, can easily be attributed to supercooling of the liquids in the latter case. Such a small amount of supercooling is unusual for a silicate system, and is attributable to the fluidity of the melts, which was noted by Sitz [12] to be greatest on the line $\mathrm{CaO} . \mathrm{SiO}_{2}-\mathrm{CaO} . \mathrm{Fe}_{2} \mathrm{O}_{3}$. If Iwase and Niskioka's mixtures of $\mathrm{CaO} . \mathrm{SiO}_{2}-\mathrm{CaO} . \mathrm{Fe}_{2} \mathrm{O}_{3}$ are plotted on the ternary diagram, the cooling-curve breaks, interpreted by them to indicate the melting point of the primary phase, are seen rather to indicate boundary temperatures, while the actual liquidus temperatures are, in some cases, as much as $200^{\circ} \mathrm{C}$ higher.

TABLE 2.-Composition of and data on preparations determining the $\alpha$-monocalcium silicate field




TABLE 2.-Composition of and data on preparations determining the $\alpha$-monocalcium silicate field-Continued

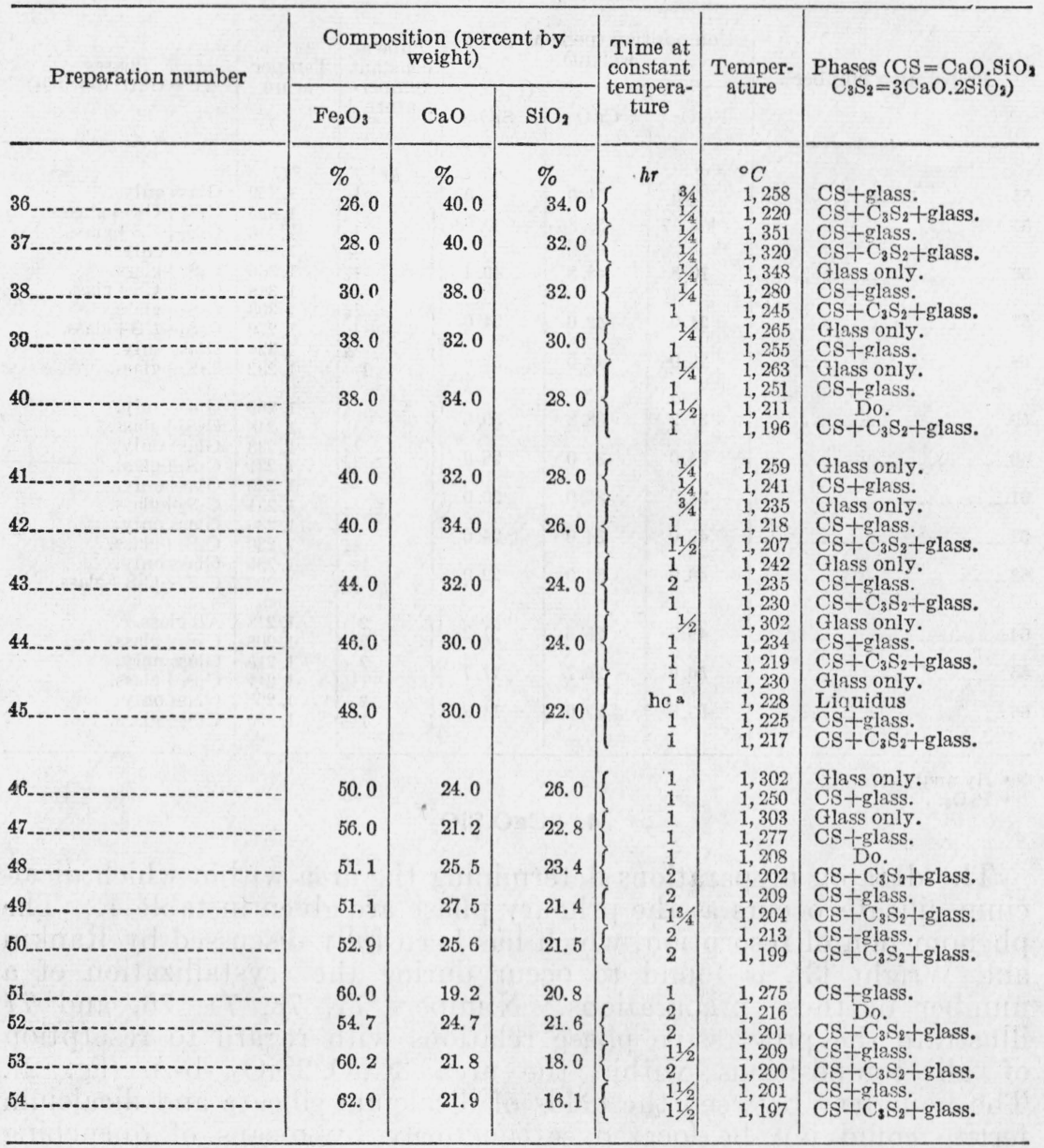

a he indicates data obtained from heating curves. Under the column headed "Phases", the data given in such cases represent interpretations placed on breaks of heating curves.

\section{3. $3 \mathrm{CaO} .2 \mathrm{SiO}_{2}$}

The data on preparations which determine the area within which tricalcium disilicate is the primary phase are given in table 3. In many preparations rich in ferric oxide (table 2) the occurrence of $3 \mathrm{CaO} .2 \mathrm{SiO}_{2}$ as the second solid phase to appear on cooling indicates the existence of this field somewhat farther than is shown in the figures. Preparations treated for 1 hour or more before quenching showed large, well-formed crystals of the primary phase. In abutting fields in which $3 \mathrm{CaO} .2 \mathrm{SiO}_{2}$ occurred as the secondary phase, the crystals also formed easily and grew to large sizes. 
TABLE 3.-Composition of and data on preparations determining the tricalcium disilicate field

\begin{tabular}{|c|c|c|c|c|c|c|}
\hline \multirow{2}{*}{ Preparation number } & \multicolumn{3}{|c|}{$\begin{array}{l}\text { Composition (percentage by } \\
\text { weight) }\end{array}$} & \multirow{2}{*}{$\begin{array}{c}\text { Time at } \\
\text { constant } \\
\text { temper- } \\
\text { ature }\end{array}$} & \multirow{2}{*}{$\begin{array}{l}\text { Temper- } \\
\text { ature }\end{array}$} & \multirow{2}{*}{$\begin{array}{c}\text { Phases } \\
\left(\mathrm{C}=\mathrm{CaO} ; \mathrm{S}=\mathrm{SiO}_{2}\right)\end{array}$} \\
\hline & $\mathrm{Fe}_{2} \mathrm{O}_{3}$ & $\mathrm{CaO}$ & $\mathrm{SiO}_{2}$ & & & \\
\hline 55 & $\stackrel{\%}{2.0}$ & $\begin{array}{l}\% \\
54.0\end{array}$ & $\begin{array}{l}\% \\
44.0\end{array}$ & & $\begin{array}{l}{ }^{\circ} \mathrm{C} \\
1,459\end{array}$ & \multirow{5}{*}{$\begin{array}{l}\text { Glass only. } \\
\mathrm{C}_{3} \mathrm{~S}_{2}+\mathrm{C}_{2} \mathrm{~S}+\text { glass. } \\
\mathrm{C}_{3} \mathrm{~S}_{2}+\mathrm{CS}+\text { glass. } \\
\mathrm{Glass} \text { only. } \\
\mathrm{C}_{3} \mathrm{~S}_{2}+\text { glass. } \\
\mathrm{C}_{3} \mathrm{~S}_{2}+\mathrm{CS}+\text { glass. } \\
\mathrm{C}_{3} \mathrm{~S}_{2}+\text { glass. } \\
\mathrm{C}_{3} \mathrm{~S}_{2}+\mathrm{CS}+\text { glass. } \\
\mathrm{Gllass} \text { only. } \\
\mathrm{C}_{3} \mathrm{~S}_{2}+\text { glass. }\end{array}$} \\
\hline $55 \therefore$ & b 2.17 & 53.86 & 43.68 & \{ & 1,455 & \\
\hline $56 \ldots$ & 10.8 & & & 4 & $\begin{array}{l}1,385 \\
1,366 \\
1,348\end{array}$ & \\
\hline 57. & 24.0 & 42.0 & 34.0 & 1 & $\begin{array}{l}1,308 \\
1,270\end{array}$ & \\
\hline 58 & 26.0 & 42.0 & 32.0 & $1^{1 / 4}$ & $\begin{array}{l}1,324 \\
1,282\end{array}$ & \\
\hline $59 \ldots$ & 31.2 & 38.8 & 30.0 & $1 / 4$ & $\begin{array}{l}1,269 \\
1,248\end{array}$ & $\begin{array}{l}\text { Glass only. } \\
\mathrm{C}_{3} \mathrm{~S}_{2}+\text { glass. }\end{array}$ \\
\hline 60 & 34.0 & 38.0 & 28.0 & $\begin{array}{l}1 \\
1 \\
1 / 4\end{array}$ & 1,233 & Glass only. \\
\hline $61 .$. & 38.0 & 36.0 & 26.0 & & 1,240 & Glass only. \\
\hline 62 & 42.0 & 34.0 & 24.0 & $\begin{array}{l}14 \\
1 / 4 \\
1 / 4\end{array}$ & 1,236 & Glass only. \\
\hline 63. & 46.0 & 32.0 & 22.0 & 1 & $\begin{array}{l}1,235 \\
1,222\end{array}$ & $\begin{array}{l}\text { Glass only. } \\
\mathrm{C}_{3} \mathrm{~S}_{2}+\mathrm{C}_{2} \mathrm{~S}+\text { glass. }\end{array}$ \\
\hline $64 \ldots$ & 49.3 & 29.5 & 21.2 & $\begin{array}{l}2 \\
2\end{array}$ & $\begin{array}{l}1,218 \\
1,206\end{array}$ & $\begin{array}{l}\text { All glass. } \\
\mathrm{C}_{3} \mathrm{~S}_{2}+\text { glass. }\end{array}$ \\
\hline $65 \ldots$ & 56.6 & 25.7 & 17.7 & 2 & 1,215 & Glass only. \\
\hline 66 & 63.8 & 22.0 & 14.2 & $\begin{array}{l}2 \\
11 / 2\end{array}$ & $\begin{array}{l}1,206 \\
1,190\end{array}$ & $\begin{array}{l}\text { Glass only. } \\
\mathrm{C}_{3} \mathrm{~S}_{2}+\text { glass. }\end{array}$ \\
\hline
\end{tabular}

a By analysis.

b $\mathrm{R}_{2} \mathrm{O}_{3}$.

4. $2 \mathrm{CaO} . \mathrm{SiO}_{2}$

The data on preparations determining the area within which dicalcium silicate occurs as the primary phase are given in table 4 . The phenomenon of resorption, which has been fully discussed by Rankin and Wright [3], is found to occur during the crystallization of a number of these preparations. Numbers $71,73,74,76$, and 77 illustrate the progressive phase relations with regard to resorption of all compositions within the area $3 \mathrm{CaO} .2 \mathrm{SiO}_{2}$. -b-A (fig. 2). The boundary between the fields of dicalcium silicate and dicalcium ferrite could not be located satisfactorily by means of quenching experiments, because the preparations were characterized by profuse quench crystals of the calcium ferrites. The determination of the primary phase in the region of this boundary would require a clearer distinction than has been found between ferrite crystals formed on quenching and those that are in equilibrium with liquid at the temperatures of the quench.

It has been shown that the formation of two limited solid-solution series between the calcium borates and dicalcium silicate has a marked effect upon the $\alpha-\beta$ inversion temperature and upon the index of refraction of the dicalcium silicate [13]. The addition of $\mathrm{Fe}_{2} \mathrm{O}_{3}$ to $2 \mathrm{CaO} \cdot \mathrm{SiO}_{2}$ causes a maximum lowering of the $\alpha-\beta$ inversion temperature of about 60 degrees (table 5 and fig. 3). Since the addition of 0.5 percent of $\mathrm{Fe}_{2} \mathrm{O}_{3}$ by weight causes a lowering of the inversion temperature of 60 degrees and the addition of larger percentages causes no further lowering, it is believed that the limit of solid solution of $\mathrm{Fe}_{2} \mathrm{O}_{3}$ in dicalcium silicate is not more than 0.5 percent. No varia- 
tion in the indices of the dicalcium silicate was noted-thus this property cannot be used to indicate the presence of solid solution.

The extent of the solid solution of $\mathrm{Fe}_{2} \mathrm{O}_{3}$ in $\beta$-dicalcium silicate was determined also by treating mixtures of these two materials at appropriate temperatures below the melting points of either material, quenching, and examining microscopically for the presence of glass. ${ }^{2}$ Dicalcium silicate prepared in the ordinary way proved unsuitable for this purpose, since the compound on quenching always inverted to the low temperature $(\gamma)$ form. However, if the initial mixture was prepared from the crystalline, hydrated, dicalcium silicate $10 \mathrm{CaO}$.$5 \mathrm{SiO}_{2} \cdot 6 \mathrm{H}_{2} \mathrm{O}$, this inversion did not occur.

In discussing their experiments on the hydration of dicalcium. silicate, Keevil and Thorvaldson [14] describe three crystalline forms

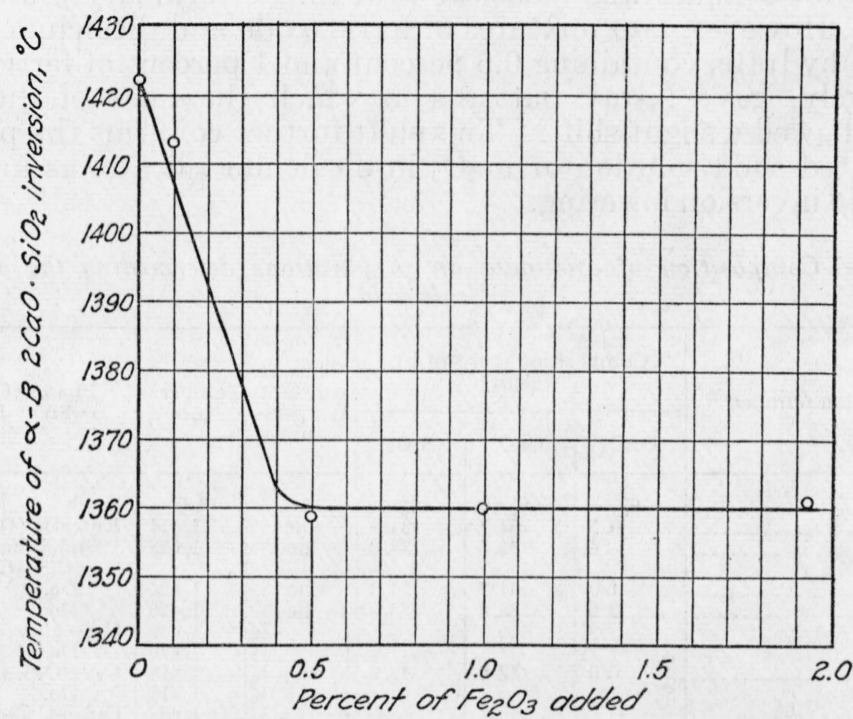

Figure 3.-Effect of $\mathrm{Fe}_{2} \mathrm{O}_{3}$ on the $\alpha-\beta-2 \mathrm{CaO} . \mathrm{SiO}_{2}$ inversion temperature.

of hydrated dicalcium silicate. It was reported that two forms retained their original crystal structure after ignition at $900^{\circ} \mathrm{C}$ and possessed indices of refraction considerably lower than the lower index of $\beta$-dicalcium silicate but well above those of $\gamma$-dicalcium silicate. The third and most distinctive product found in steam-treated dicalcium silicate was described as well-developed, platelike, orthorhombic crystals, with refractive indices: $\alpha=1.610 \pm 0.002$ and $\gamma=1,633 \pm 0.002$. The dehydration of this product was not discussed. Flint, McMurdie, and Wells [15] duplicated this product and suggested for it the formula $10 \mathrm{CaO} \cdot 5 \mathrm{SiO}_{2} \cdot 6 \mathrm{H}_{2} \mathrm{O}$.

Experiments in the present study proved that the treatment of $10 \mathrm{CaO} \cdot 5 \mathrm{SiO}_{2} \cdot 6 \mathrm{H}_{2} \mathrm{O}$ at $1,450^{\circ} \mathrm{C}$ resulted in $\beta$-dicalcium silicate. It is of interest to note that, (1) the platelike form is not retained, but instead the irregularly shaped crystals of $\beta$-dicalcium silicate are

\footnotetext{
2 If the dicalcium silicate is able to take up some ferric oxide in solid solution, a preparation composed of dicalcium silicate and an amount of $\mathrm{Fe}_{2} \mathrm{O}_{3}$ smaller than or equal to the limiting amount that could be held in solid solution should not form any liquid when treated at a temperature well below the melting point of dicalcium silicate. For this reason, the presence of glass in a preparation treated as above indicates that the amount of $\mathrm{Fe}_{2} \mathrm{O}_{3}$ in the mixture exceeds the amount that can be held in solid solution.
} 
observed, (2) normal indices of refraction for $\beta$-dicalcium silicate are obtained, and (3) the $\beta-\gamma$ inversion is prevented. Keevil and Thorvaldson suggest that the finely divided form of their dehydrated products prevents the inversion of the $\beta$-form to the $\gamma$-form. However, it is here shown that dehydrated $10 \mathrm{CaO} \cdot 5 \mathrm{SiO}_{2} \cdot 6 \mathrm{H}_{2} \mathrm{O}$ does not invert to the $\gamma$-form, even though occurring in large crystals.

Mixtures of dicalcium silicate and ferric oxide containing 2 percent, 1 percent, and 0.5 percent of ferric oxide, treated for 17 hours at $1,350^{\circ}$ to $1,360^{\circ} \mathrm{C}$, consisted, upon quenching, of $\beta-2 \mathrm{CaO} \cdot \mathrm{SiO}_{2}$ and glass. Thus, if there is solid solution of ferric oxide in dicalcium silicate, as indicated by the lowering of the $\alpha-\beta$ inversion temperature, the limit is probably not more than 0.5 percent of ferric oxide.

The X-ray pattern of a sample of $10 \mathrm{CaO} \cdot 5 \mathrm{SiO}_{2} \cdot 6 \mathrm{H}_{2} \mathrm{O}$ treated at $1,350^{\circ} \mathrm{C}$ for 3 hours was identical with that of ordinary $\beta$-dicalcium silicate. However, two mixtures of ferric oxide and dicalcium silicate from the hydrate, containing 0.5 percent and 1 percent of ferric oxide, respectively, gave X-ray patterns in which the lines of dicalcium silicate showed a slight shift. This shift further confirms the presence of a limited solid solution of $\mathrm{Fe}_{2} \mathrm{O}_{3}$ in dicalcium silicate, as indicated by the $\alpha-\beta$ inversion lowering.

TABLE 4.-Composition of and data on preparations determining the dicalcium silicate field

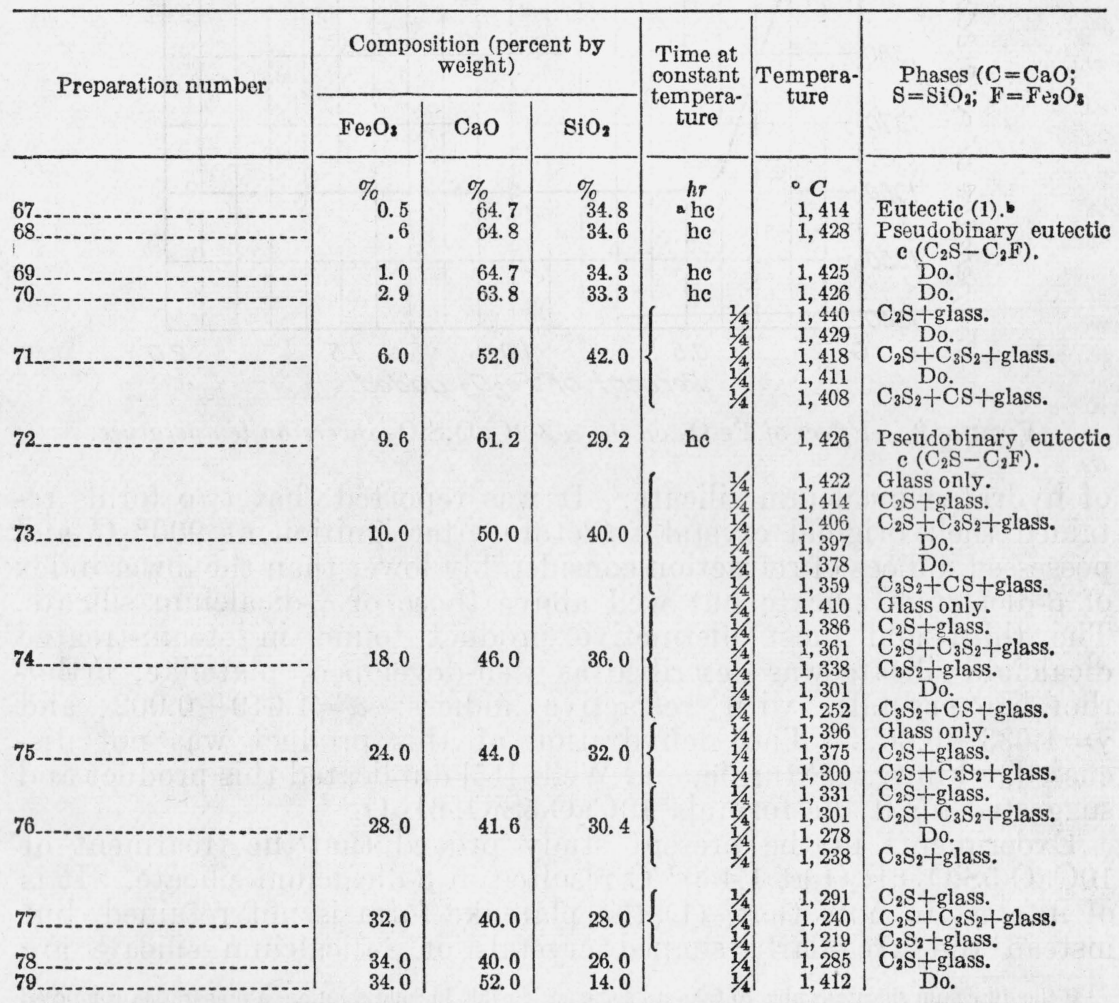

"he indicates data obtained from heating curves. Under the column headed "Phases," the data given in such cases represent interpretations placed on breaks of heating curves.

Numbers in parentheses refer to points in figure 2. 
TABLE 4.-Composition of and data on preparations determining the dicalcium silicate field-Continued

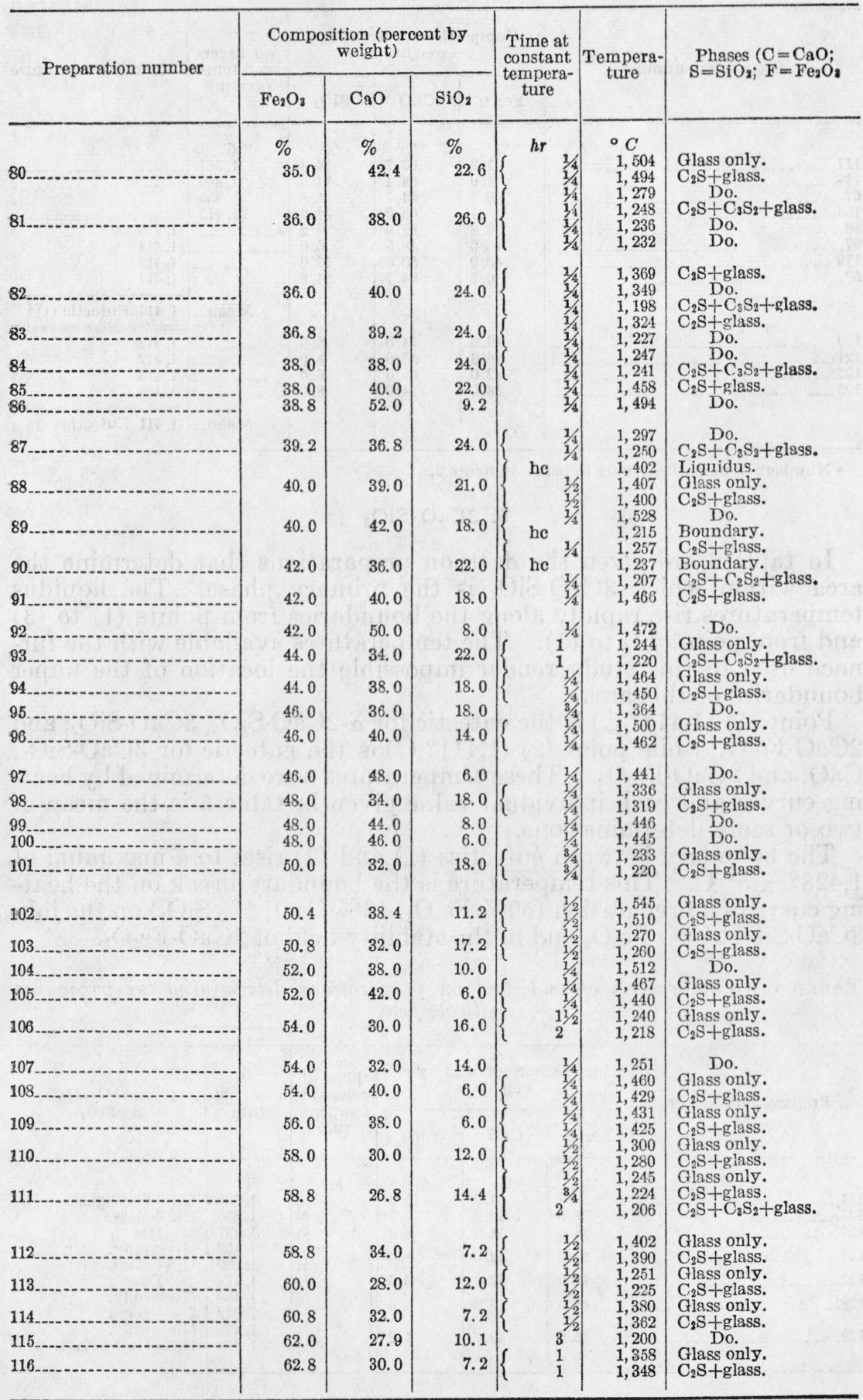


TABLE 5.-Data showing the lowering of the $\alpha$ - $\beta$ dicalcium silicate inversion temperature and determining the temperature of eutectics (1) and (2)

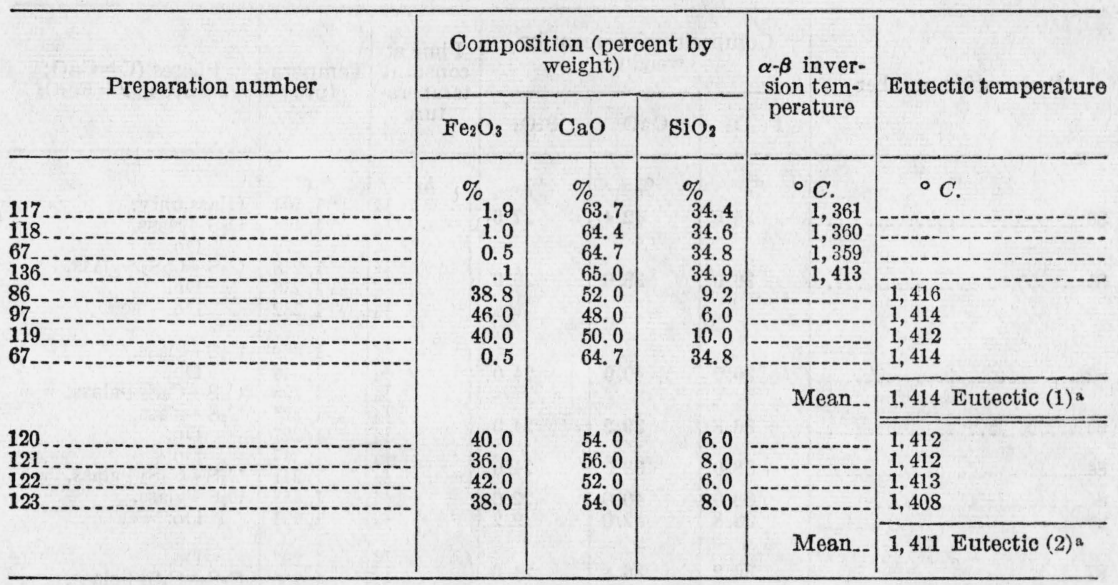

- Numbers in parentheses refer to points in figure 2.

\section{5. $3 \mathrm{CaO} \cdot \mathrm{SiO}_{2}$}

In table 6 are given the data on preparations that determine the area within which $3 \mathrm{CaO} \cdot \mathrm{SiO}_{2}$ is the primary phase. The liquidus temperatures rise rapidly along the boundaries from points (1) to (3) and from points (2) to (3). The temperatures available with the furnace used in this study render impossible the location of the upper boundaries of this area.

Point (1) $\left(1,414^{\circ} \mathrm{C}\right)$ is the eutectic for $\alpha-2 \mathrm{CaO} \cdot \mathrm{SiO}_{2}, 3 \mathrm{CaO} \cdot \mathrm{SiO}_{2}$, and $2 \mathrm{CaO} \cdot \mathrm{Fe}_{2} \mathrm{O}_{3}$, while point $(2)\left(1,411^{\circ} \mathrm{C}\right)$ is the eutectic for $3 \mathrm{CaO} \cdot \mathrm{SiO}_{2}$, $\mathrm{CaO}$, and $2 \mathrm{CaO} \cdot \mathrm{Fe}_{2} \mathrm{O}_{3}$. These temperatures were determined by heating curves and each individual value given in table 5 is the mean of two or more determinations.

The boundary between eutectics (1) and (2) rises to a maximum of $1,428^{\circ} \pm 5^{\circ} \mathrm{C}$. This temperature is the boundary break on the heating curve of a preparation $\left(50 \% \mathrm{Fe}_{2} \mathrm{O}_{3}, 46 \% \mathrm{CaO}, 4 \% \mathrm{SiO}_{2}\right)$ on the join $3 \mathrm{CaO} \cdot \mathrm{SiO}_{2}-2 \mathrm{CaO} \cdot \mathrm{Fe}_{2} \mathrm{O}_{3}$ and in the stability field of $2 \mathrm{CaO} \cdot \mathrm{Fe}_{2} \mathrm{O}_{3}$.

TABLE 6.-Composition of and data on preparations determining the tricalcium silicate field

\begin{tabular}{|c|c|c|c|c|c|c|}
\hline \multirow{2}{*}{ Preparation number } & \multicolumn{3}{|c|}{$\begin{array}{c}\text { Composition (percent by } \\
\text { weight) }\end{array}$} & \multirow{2}{*}{$\begin{array}{l}\text { Time at } \\
\text { constant } \\
\text { tempera- } \\
\text { ture }\end{array}$} & \multirow{2}{*}{$\begin{array}{c}\text { Tempera- } \\
\text { ture }\end{array}$} & \multirow{2}{*}{$\begin{array}{c}\text { Phases }(\mathrm{C}=\mathrm{CaO} ; \\
\left.\mathrm{S}=\mathrm{SiO}_{2}\right)\end{array}$} \\
\hline & $\mathrm{Fe}_{2} \mathrm{O}_{3}$ & $\mathrm{CaO}$ & $\mathrm{SiO}_{2}$ & & & \\
\hline $\begin{array}{l}124 \ldots \\
125 \ldots- \\
126 \ldots\end{array}$ & $\begin{array}{c}\% \\
36.0 \\
37.6 \\
38.0\end{array}$ & $\begin{array}{c}\% \\
54.0 \\
53.2 \\
54.0\end{array}$ & \begin{tabular}{r}
\multicolumn{1}{c}{} \\
10.0 \\
9.2 \\
8.0
\end{tabular} & \multirow{5}{*}{$h r \quad$\begin{tabular}{r|}
$1 / 2$ \\
$1 / 2$ \\
$1 / 4$ \\
$1 / 4$ \\
14 \\
$1 / 4$ \\
$1 / 4$ \\
11 \\
$1 / 4$ \\
$1 / 4$
\end{tabular}} & \multirow{5}{*}{$\begin{array}{l}{ }^{\circ} C \\
1,530 \\
1,536 \\
1,497 \\
1,499 \\
1,480 \\
1,478 \\
1,468 \\
1,449 \\
1,429 \\
1,412\end{array}$} & \multirow{5}{*}{$\begin{array}{l}\mathrm{C}_{3} \mathrm{~S}+\mathrm{C}_{2} \mathrm{~S}+\text { glass. } \\
\mathrm{C}_{3} \mathrm{~S}+\text { +lass. } \\
\text { Do. } \\
\text { Dlass only. } \\
\mathrm{C}_{3} \mathrm{~S}+\text { glass. } \\
\text { Do. } \\
\text { Glass only. } \\
\mathrm{C}_{3} \mathrm{~S}+\text { glass. } \\
\text { Glass only. } \\
\mathrm{C}_{3} \mathrm{~S}+\mathrm{CaO}+\text { glass. }\end{array}$} \\
\hline 127 & 40.0 & 52.0 & 8.0 & & & \\
\hline 122 & 42.0 & 52.0 & 6.0 & & & \\
\hline 128 & 44.0 & 50.0 & 6.0 & & & \\
\hline 129 & 45.6 & 49.2 & 5.2 & & & \\
\hline
\end{tabular}




\section{6. $\mathrm{CaO}$}

The data on several preparations in which $\mathrm{CaO}$ occurs as the primary phase are given in table 7 .

TABLE 7.-Composition of and data on preparations determining the calcium oxide field

\begin{tabular}{|c|c|c|c|c|c|c|}
\hline \multirow{2}{*}{ Preparation number } & \multicolumn{3}{|c|}{$\begin{array}{c}\text { Composition (percentage by } \\
\text { weight) }\end{array}$} & \multirow{2}{*}{$\begin{array}{c}\text { Time at } \\
\text { constant } \\
\text { temper- } \\
\text { ature }\end{array}$} & \multirow{2}{*}{$\begin{array}{c}\text { Temper- } \\
\text { ature }\end{array}$} & \multirow{2}{*}{$\begin{array}{r}\text { Phases }(\mathrm{C}=\mathrm{CaO} ; \\
\left.\mathrm{S}=\mathrm{SiO}_{2} ; \mathrm{F}=\mathrm{Fe}_{2} \mathrm{O}_{3}\right)\end{array}$} \\
\hline & $\mathrm{Fe}_{2} \mathrm{O}_{3}$ & $\mathrm{CaO}$ & $\mathrm{SiO}_{2}$ & & & \\
\hline $\begin{array}{l}121 \\
120 \\
130\end{array}$ & $\begin{array}{l}\% \\
36.0 \\
40.0 \\
44.0\end{array}$ & $\begin{array}{l}\% \\
\text { 56.0 } \\
54.0 \\
52.0\end{array}$ & $\begin{array}{l}\%_{8.0} \\
6.0 \\
4.0\end{array}$ & $\begin{array}{ll}h r \quad \\
1 / 4 \\
1 / 4 \\
1 / 4\end{array}$ & $\begin{array}{l}{ }^{\circ} C \\
1,532 \\
1,480 \\
1,446\end{array}$ & $\begin{array}{l}\mathrm{CaO}+\mathrm{C}_{3} \mathrm{~S}+\text { glass. } \\
\mathrm{CaO}+\text { glass. } \\
\text { Do. }\end{array}$ \\
\hline 131 & 46.0 & 50.0 & 4.0 & $\begin{array}{l}11 / 4 \\
1 / 4\end{array}$ & $\begin{array}{l}1,447 \\
1,427\end{array}$ & $\begin{array}{l}\text { Do. } \\
\mathrm{CaO}+\mathrm{C}_{3} \mathrm{~S}+\text { glass. }\end{array}$ \\
\hline 132 & 48.0 & 48.0 & 4.0 & $\begin{array}{l}1 / 4 \\
1 / 4 \\
1 / 4\end{array}$ & $\begin{array}{l}1,443 \\
1,435 \\
1,348\end{array}$ & $\begin{array}{l}\text { Glass only. } \\
\mathrm{CaO}+\text { glass. } \\
\mathrm{CaO}+\mathrm{C}_{3} \mathrm{~S}+\mathrm{C}_{2} \mathrm{~F} \text {. }\end{array}$ \\
\hline
\end{tabular}

\section{REDUCTION OF FERRIC OXIDE IN TERNARY MIXTURES}

The reduction of ferric oxide in the system $\mathrm{CaO}-\mathrm{Fe}_{2} \mathrm{O}_{3}$ [6] was reported as negligible in mixtures containing less than about 74 percent by weight of ferric oxide. Since some of the ternary mixtures developed magnetic properties after treatment at high temperatures, an indication of the amount of reduction of $\mathrm{Fe}_{2} \mathrm{O}_{3}$ was desired. Determinations of ferrous oxide were made on several charges containing between 12 and 63 percent of ferric oxide and between 6 and 56 percent of silica and located in the various fields delimited. The preparations used in these tests were wrapped in platinum foil, treated at about their liquidus temperature for 15 minutes, and quenched in air. The resulting material was coarsely ground and the platinum separated by means of a sieve. Weighed samples were treated with hot dilute $\mathrm{HCl}$ in an atmosphere of carbon dioxide until all except the silica was dissolved. The solution was diluted with air-free water, a phosphoric and sulfuric acid mixture was added, and the ferrous oxide determined by titration with potassium dichromate.

TABLE 8.-Ferrous oxide content of several representative preparations

\begin{tabular}{|c|c|c|c|c|c|c|c|}
\hline \multirow{2}{*}{$\begin{array}{l}\text { Preparation } \\
\text { number }\end{array}$} & \multicolumn{3}{|c|}{ Composition (percentage by weight) } & \multirow{2}{*}{$\begin{array}{c}\text { Primary } \\
\text { phase } \\
(\mathrm{C}=\mathrm{CaO} \\
\left.\mathrm{S}=\mathrm{SiO}_{2}\right)\end{array}$} & \multirow{2}{*}{$\begin{array}{c}\text { Tempera- } \\
\text { ture }\end{array}$} & \multirow{2}{*}{$\begin{array}{c}\text { Time at } \\
\text { constant } \\
\text { tempera- } \\
\text { ture }\end{array}$} & \multirow{2}{*}{$\mathrm{FeO}$} \\
\hline & $\mathrm{Fe}_{2} \mathrm{O}_{3}$ & $\mathrm{CaO}$ & $\mathrm{SiO}_{2}$ & & & & \\
\hline $\begin{array}{l}66 \\
109 \\
133 \\
128 \\
181 \\
1341 \\
1351 \\
35\end{array}$ & $\begin{array}{l}\%_{63.8} \\
63.8 \\
56.0 \\
48.0 \\
44.0 \\
40.1 \\
40.0 \\
35.8 \\
31.6 \\
16.0 \\
12.0\end{array}$ & $\begin{array}{r}\%^{2} .0 \\
22.0 \\
38.0 \\
38.0 \\
50.0 \\
19.2 \\
32.0 \\
37.5 \\
33.1 \\
46.0 \\
32.0\end{array}$ & $\begin{array}{r}\%_{14.2} \\
6.0 \\
14.0 \\
6.0 \\
40.7 \\
28.0 \\
26.8 \\
35.2 \\
38.0 \\
56.0\end{array}$ & $\begin{array}{l}\mathrm{C}_{3} \mathrm{~S}_{2} \\
\mathrm{C}_{2} \mathrm{~S} \\
\mathrm{C}_{2} \mathrm{~S} \\
\mathrm{C}_{3} \mathrm{~S} \\
\mathrm{SiO}_{2} \\
\mathrm{CS} \\
\mathrm{C}_{2} \mathrm{~S} \\
\mathrm{CS} \\
\mathrm{CS} \\
\mathrm{CS}\end{array}$ & $\begin{array}{l}{ }^{\circ} C \\
1,200 \\
1,400 \\
1,400 \\
1,400 \\
1,300 \\
1,250 \\
1,410 \\
1,400 \\
1,400 \\
1,350\end{array}$ & $\begin{array}{l}1 / 4 \\
1 / 4 \\
1 / 4 \\
1 / 4 \\
1 / 4 \\
1 / 4 \\
1 / 4 \\
1 / 4 \\
1 / 4 \\
1 / 4\end{array}$ & $\begin{array}{r}\% \\
0.7 \\
1.0 \\
1.1 \\
0.0 \\
2.8 \\
0.9 \\
.8 \\
3.0 \\
0.9 \\
3.1\end{array}$ \\
\hline
\end{tabular}

1 These compositions were prepared and analyzed in connection with another study and were treated at about $100^{\circ} \mathrm{C}$ above their liquidus temperatures.

The results are given in table 8 . The reduction of ferric oxide increases with the temperature and with the amount of silica present. 
the latter appearing to be the more potent factor. The amounts or ferrous oxide found are not believed to cause a significant error in the diagram.

\section{APPLICATIONS}

The specifications generally in use for either moderate or low heat of hydration cements, and for sulfate-resisting cements, demand a low alumina and a high iron oxide content. Consequently, the data obtained in this investigation are of interest industrially in the production of such cements. The following indicate certain applications.

It has been shown by Kühl [16] that cements of the portland cement type can be produced in the system lime-ferric oxide-silica. The composition range of alumina-free cements having satisfactory strengths and setting properties has been delimited by Kühl as being within the elliptical area enclosed by a continuous line in figure 2 . For comparison, the field representing the compositions of portland cement in the system lime-silica- $\mathrm{R}_{2} \mathrm{O}_{3}$, in which $\mathrm{R}_{2} \mathrm{O}_{3}$ is considered as alumina, has been indicated by the elliptical area within the broken line. As can be seen, the substitution of ferric oxide for alumina results in a marked enlargement of the field in which satisfactory cements can be obtained.

Bogue [17] has described the manner in which the oxide components of portland cement containing $\mathrm{SiO}_{2}, \mathrm{Al}_{2} \mathrm{O}_{3}, \mathrm{Fe}_{2} \mathrm{O}_{3}, \mathrm{CaO}$, and $\mathrm{MgO}$, alone, react or combine:

(1) The ferric oxide reacts with alumina and lime to form $4 \mathrm{CaO}$. $\mathrm{Al}_{2} \mathrm{O}_{3} \cdot \mathrm{Fe}_{2} \mathrm{O}_{3}$.

$\mathrm{MgO}$.

(3) The alumina remaining after the formation of the compound $4 \mathrm{CaO} \cdot \mathrm{Al}_{2} \mathrm{O}_{3} \cdot \mathrm{Fe}_{2} \mathrm{O}_{3}$ reacts with lime to form $3 \mathrm{CaO} \cdot \mathrm{Al}_{2} \mathrm{O}_{3}$.

(4) The lime remaining after the formation of the above compounds reacts with silica. The compound $2 \mathrm{CaO} \cdot \mathrm{SiO}_{2}$ is formed, and any $\mathrm{CaO}$ then uncombined reacts with the $2 \mathrm{CaO} \cdot \mathrm{SiO}_{2}$ to form $3 \mathrm{CaO} \cdot \mathrm{SiO}_{2}$. If $\mathrm{CaO}$ remains after converting all of the $2 \mathrm{CaO} \cdot \mathrm{SiO}_{2}$ to $3 \mathrm{CaO} \cdot \mathrm{SiO}_{2}$, it will be present as uncombined lime.

When the $\mathrm{R}_{2} \mathrm{O}_{3}$ content of cements containing $\mathrm{SiO}_{2}, \mathrm{Al}_{2} \mathrm{O}_{3}, \mathrm{Fe}_{2} \mathrm{O}_{3}$, and $\mathrm{CaO}$, alone, is predominately ferric oxide, the limit of lime content is decreased because of the difference in combining ratios of the aluminum and ferric oxides. In such portland cements the alumina reacting with lime to form $3 \mathrm{CaO} \cdot \mathrm{Al}_{2} \mathrm{O}_{3}$ requires 1.65 parts of $\mathrm{CaO}$ for 1 part of alumina, but in the iron-rich cements the ferric oxide not in solid solution with dicalcium silicate or in combination as $4 \mathrm{CaO} \cdot \mathrm{Al}_{2} \mathrm{O}_{3}$. $\mathrm{Fe}_{2} \mathrm{O}_{3}$ probably forms dicalcium ferrite, in which 1 part of ferric oxide requires only 0.70 part of $\mathrm{CaO}$. Thus more lime remains for combination with silica and the minimum lime content is lowered.

Lowering the $\mathrm{SiO}_{2}-\mathrm{R}_{2} \mathrm{O}_{3}$ ratio in portland cements having an $\mathrm{Al}_{2} \mathrm{O}_{3}$ $\mathrm{Fe}_{2} \mathrm{O}_{3}$ ratio of between 0.6 and 1.6 results in the formation of increasing amounts of tricalcium aluminate. If this compound is in excess, difficulty with rapid setting of the cement is encountered. Lower $\mathrm{SiO}_{2}-\mathrm{R}_{2} \mathrm{O}_{3}$ ratios are possible in iron-rich cements than in the portland type because of the formation of dicalcium ferrite, which hydrates rapidly but does not have the flash-setting property characteristic of tricalcium aluminate. 
The liquidus temperatures of preparations within the dicalcium silicate field of the system lime-alumina-silica are lowered little, if any, by the substitution of ferric oxide for alumina, but the temperature at which liquid is first formed is appreciably reduced. The majority of modern portland cement compositions are within the triangle $2 \mathrm{CaO} \cdot \mathrm{SiO}_{2}-3 \mathrm{CaO} \cdot \mathrm{SiO}_{2}-3 \mathrm{CaO} \cdot \mathrm{Al}_{2} \mathrm{O}_{3}$ of the system lime-alumina-silica. Compositions within this area have a eutectic temperature of $1,455^{\circ} \mathrm{C}$. Substitution of ferric oxide for alumina, a condition which is approached in the case of high-iron cements, results in eutectic temperatures of $1,411^{\circ} \mathrm{C}$ for the triangle $3 \mathrm{CaO} \cdot \mathrm{SiO}_{2}-\mathrm{CaO}-2 \mathrm{CaO} \cdot \mathrm{Fe}_{2} \mathrm{O}_{3}$ or $1,414^{\circ} \mathrm{C}$ for the triangle $2 \mathrm{CaO} \cdot \mathrm{SiO}_{2}-3 \mathrm{CaO} \cdot \mathrm{SiO}_{2}-2 \mathrm{CaO} \cdot \mathrm{Fe}_{2} \mathrm{O}_{3}$.

An interesting relationship is observed by comparing the amounts of liquid formed at a given temperature in various cement mixtures. In table 9 are listed five oxide compositions which lie in the cement zone of the system lime-ferric oxide-silica, together with the percentage of liquid at $1,455^{\circ} \mathrm{C}$, when the $\mathrm{R}_{2} \mathrm{O}_{3}$ is all $\mathrm{Al}_{2} \mathrm{O}_{3}$ and when it consists of $\mathrm{Fe}_{2} \mathrm{O}_{3}$. It is seen that, although the use of ferric oxide brings about the formation of liquid at lower temperatures than alumina does, the ferric oxide mixtures result in the formation of smaller amounts of liquid than those in which alumina is used.

TABLE 9.-Liquid content of cement mixtures in the system lime-ferric oxide-silica at $1,455^{\circ} \mathrm{C}$

[The amount of liquid that would result from a percentage substitution of $\mathrm{Al}_{2} \mathrm{O}_{3}$ for $\mathrm{Fe}_{3} \mathrm{O}_{3}$ in these mixtures: is also given]

\begin{tabular}{|c|c|c|c|c|c|}
\hline \multirow{2}{*}{ Number } & \multicolumn{2}{|c|}{$\begin{array}{c}\text { Composition (percentage by } \\
\text { weight) }\end{array}$} & \multicolumn{2}{c|}{ Percentage liquid when- } \\
\cline { 2 - 6 } & $\mathrm{CaO}$ & $\mathrm{SiO}_{2}$ & $\mathrm{R}_{2} \mathrm{O}_{3}$ & $\mathrm{R}_{2} \mathrm{O}_{3}=\mathrm{Fe}_{2} \mathrm{O}_{3}$ & $\mathrm{R}_{2} \mathrm{O}_{3}=\mathrm{Al}_{3} \mathrm{O}_{3}$ \\
\hline & $\%$ & $\%$ & $\%$ & $\%$ & $\%$ \\
1 & 64 & 30 & 6 & 13 & 18 \\
2 & 62 & 28 & 10 & 22 & 31 \\
3 & 62 & 24 & 14 & 31 & 43 \\
4 & 66 & 20 & 14 & 31 & 42 \\
5 & 68 & 26 & 6 & 13 & 19 \\
\hline
\end{tabular}

\section{SUMMARY}

The boundaries of the primary phase areas in a part of the ternary system lime-ferric oxide-silica have been established.

The effect of ferric oxide in lowering the $\alpha-\beta$ inversion temperature is offered as evidence of a limited solid solution of ferric oxide in dicalcium silicate. The limit of this solid solution is placed at not more than 0.5 percent by weight of ferric oxide. No variation in the indices of refraction of the dicalcium silicate due to solid solution was noted. However, the presence of as little as 0.5 percent of ferric oxide caused a slight shift of the lines in the X-ray patterns. The crystalline hydrated dicalcium silicate $10 \mathrm{CaO} \cdot 5 \mathrm{SiO}_{2} \cdot 6 \mathrm{H}_{2} \mathrm{O}$, after treatment at $1,350^{\circ} \mathrm{C}$, could be quenched to maintain the $\beta$-form of dicalcium silicate as verified by its X-ray pattern. Ferric oxide did not prevent the $\beta-\gamma$ inversion in quenched samples prepared from calcium carbonate and silica gel.

No ternary compounds were found in the portion of the system. investigated. 
The amount of ferrous oxide developed as a result of heating preparations in several stability fields at their liquidus temperatures for 15 minutes was determined and found to increase with increase of temperature and with higher silica contents. The largest percentage of ferrous oxide found was about 3 , which was not believed to cause a significant error in the results.

The author is indebted to H. F. McMurdie for the X-ray patterns, and acknowledges the cooperation and advice of L. S. Wells and of E. P. Flint.

\section{REFERENCES}

[1] Hansen and Bogue, Studies on the system calcium oxide-ferric oxide-silica, J. Am. Chem. Soc. 48, 1261 (1926).

[2] A. L. Day, E. S. Shepherd, and F. E. Wright, The lime-silica series of minerals, Am. J. Sci. [4] 22, 265-302 (1906).

[3] G. A. Rankin and F. E. Wright, The ternary system $\mathrm{CaO}-\mathrm{Al}_{2} \mathrm{O}_{3}-\mathrm{SiO}_{2} . \mathrm{Am}$. J. Sci. [4] 39, 1-79 (1915).

[4] J. B. Ferguson and $\mathrm{H}$. E. Merwin, The ternary system $\mathrm{CaO}-\mathrm{MgO}-\mathrm{SiO}_{2}$. Am. J. Sci. [4] 48, 81-123 (1919).

[5] J. W. Grieg, Immiscibility of silicate melts. Am. J. Sci. [5] 13, 1-44, 133-154 (1927).

[6] R. B. Sosman and H. E. Merwin, The system $\mathrm{CaO}-\mathrm{Fe}_{2} \mathrm{O}_{3}$. J. Wash. Acad. Sci. 6, 532-537 (1916).

[7] N. L. Bowen, J. F. Schairer and H. W. V. Willems, The system $\mathrm{Na}_{2} \mathrm{SiO}_{3}$ $\mathrm{Fe}_{2} \mathrm{O}_{3}-\mathrm{SiO}_{2}$. Am. J. Sci. [5] 20, 405-455 (1930).

[8] H. S. Roberts, The Geophysical Laboratory furnace thermostat, J. Opt. Soc. Am. Rev. Sci. Instr. 11, 171-186 (1925).

[9] C. N. Fenner, The stability relations of the silica minerals, Am. J. Sci. [4] 36, 351 (1913).

[10] N. L. Bowen, J. F. Schairer, and E. Posnjak, The system CaO-FeO-SiO 2 . Am. J. Sci. [5] 2\%, 206 (1933).

[11] Kiezo Iwase and Usaburo Nishioka, The equilibrium diagrams of three binary

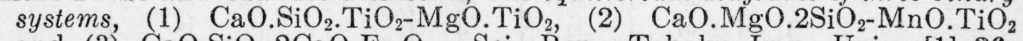
and (3) $\mathrm{CaO} . \mathrm{SiO}_{2}-2 \mathrm{CaO} . \mathrm{Fe}_{2} \mathrm{O}_{3}$. Sci. Rep., Tohoku Imp. Univ. [1] 26, $592-601$ (1938).

[12] G. Sitz, The system $\mathrm{CaO} . \mathrm{Fe}_{2} \mathrm{O}_{3} \cdot \mathrm{SiO}_{2}$ in relaiion to its significance for metallurgical slags, Metall u. Erz 29, 269 (1932).

[13] E. P. Flint and L. S. Wells, The system lime-boric oxide-silica. J. Research NBS 17, 727-752 (1936) RP941.

[14] N. B. Keevil and T. Thorvaldson, The hydration of dicalciums ilicate and tricalcium silicate, Canadian J. Research 14, 20-30 (1936).

[15] E. P. Flint, H. F. McMurdie, and L. S. Wells, Formation of hydrated calcium silicates at elevated temperatures and pressures, J. Research NBS 21, 617-638 (1938) RP1147.

[16] Hans Kühl, The cement field in the ternary system lime-ferric oxide-silica, Zement 13, 25 et seq. (1924).

[17] R. H. Bogue, Calculation of the compounds of portland cement. Ind. Eng. Chem. Anal. Ed. 1, 192 (1929).

[18] Int. Crit. Tables 1, 154 (McGraw-Hill Book Co., Inc., New York, N. Y., 1926).

Washington, August 30, 1940. 